\title{
少陽経 $\left(\mathrm{H}_{5}, \mathrm{~F}_{5}\right)$ に関して \\ （中谷博士の良導絡治療による一発見）
}

$\mathrm{H}_{5}$ は漢方では三焦経と称せられ、この三焦 経の意義について古来色々の説がある。しかし 三とは 3 つを意味するものではなく、人体を天、 人、地と分け、天は頭、人は胴体、地は上下肢 のことを云ったもので、即ち全身を意味してい る。

この全身を焦（こがす、もやす）すと云うこ とは、全身の組織蔵器を活動させるもの、即ち 自律神経の作用を意味するものと考えられる。

昔は自律神経も発見されていなかったので、 三焦と云う言葉を用いたのではなかろうか。

自律神経の作用と考えれば勿論体制神経（運 動、知覚）と共に人体の活動及び生命を司るこ とになる。従って $\mathrm{H}_{5}$ を仮りに神経系と称して も良いと思う。

それ故 $\mathrm{H}_{5}$ 良導絡は全身の神経を調整する作 用があるとして、該良導絡上の反応良導点や良 導点を治療点に用いることが出来る。

殊に神経の興奮、抑制の調整に特効がある場 合が多い。

即ち、左右の $\mathrm{H}_{5}$ 反応点に刺針直後乱れた代 表測定点が改善されることがある。

時として疼痛麻疾 (針麻酔) に用いられる良 導点も $\mathrm{H}_{5}$ 良導絡上にある。

又、鍼炎刺激過剩による異常状態に際して $\mathrm{H}_{5}$ 2 液門に刺針するときは忽ち常態に復帰する。 $\mathrm{H}_{5} 8$ 三陽絡は坐骨神経痛に、 $\mathrm{H}_{5}$ 10天井は腰痛 に速効があり、 $\mathrm{H}_{5} 9$ 四瀆は前腕㾏攣及び麻㾇に 著効がある。その他 $\mathrm{H}_{5}$ 良導絡上の各良導点及 び反応良導点は神経系疾患に著効のあるものが 多い。（代表測定点が調整されると同時に病的
東 京 鈴 木 博 助

症状が解消する)

以上の如く部分的にも亦全身的にも神経系を 調整する事実が非常に多い。これはノイロメー ターによる代表測定点利用の賜物である。

次に $\mathrm{F}_{5}$ 良導絡の発生原は胆囊である。胆䨢 は切除しても生命に異常を認めないし、又人体 に必要欠くべからざる重要な蔵器でもない。

然るにここから発生した F ${ }_{5}$ 良導絡は頭部か ら足部に亘り人体の両側面全域に存在している。 斯様に人体の両側面全域に良導絡が存在してい ることは重要な役目を有していることを意味す る。

発生学的に人体を考えてみるに、母体内で胎 児は先づ䏍椎骨が出来、次いで頭部及び全身の 形態並びに諸臓器が出来ると云われている。

この形態としては巾と長さと厚さという立体 が生ずる。 $\mathrm{F}_{5}$ 良導絡が人体の両側に存在する ということは、その巾に当るものであって、又 同時に形態を作っていることを意味する。

形態に於いてその外隔を形成しているものは (細胞から成る所の) 皮虚及び筋肉である。

従って皮虐及び筋肉を左右するものが $F_{5}$ 良 導絡と云える。 $F_{5}$ 良導絡は胆系と称せられて いるが、本質は（皮膚、筋肉）系と考えて良い と思う。即ち全身の皮䖉、筋肉を保護、活動、 調整する良導絡と称しても差支ないと思う。

又皮膚、笳肉は内臟に関係が深いため、内臟 の保護、活動、調整にも作用することは想像に 難くない。

殊に $\mathrm{F}_{5}$ 良導絡が頭部に左右広範囲に存在す ることは、頭蓋内外を始め、眼、耳、鼻等に対 
して保護、活動、調整の任に当っていることを 証するものである。

要するに $F_{5}$ 良導絡は人体の五官器に作用し ていることを示している。

以上のことから $\mathrm{F}_{5}$ 良導絡は諸種の疾患に治 効があるけれども、特に五官器及び（胎生上) 婦人科疾患に治効があることは申す迄もない。

併し乍ら古来の経験をみるに $\mathrm{F}_{5}$ 良導絡は $\mathrm{H}_{5}$ 良導絡と同様器質的疾患よりは官能的疾患に適 応症が多い。
殊に運動系疾患や疼痛疾患等には $\mathrm{H}_{5} 、 \mathrm{~F}_{5}$ 両 良導絡上の治療点を用いることによって著効を 来すことが多い。

良導絡（経絡）の原理について東洋医学的、 近代医学的と双方の見地から研究してみるとき に、今日迄発見出来なかった色々のことがらが 漸次現出して来ると思う。

これによって従来より以上に治効を挙げられ る方法が発見可能となり、又今日、難症として 厚生省が発表されている諸疾患の治療にも相当 効果ある方法を開発出来ると思う。

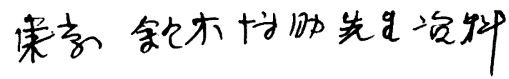

$$
H_{s}, F_{5} \text { 良絡力䧎係 }
$$
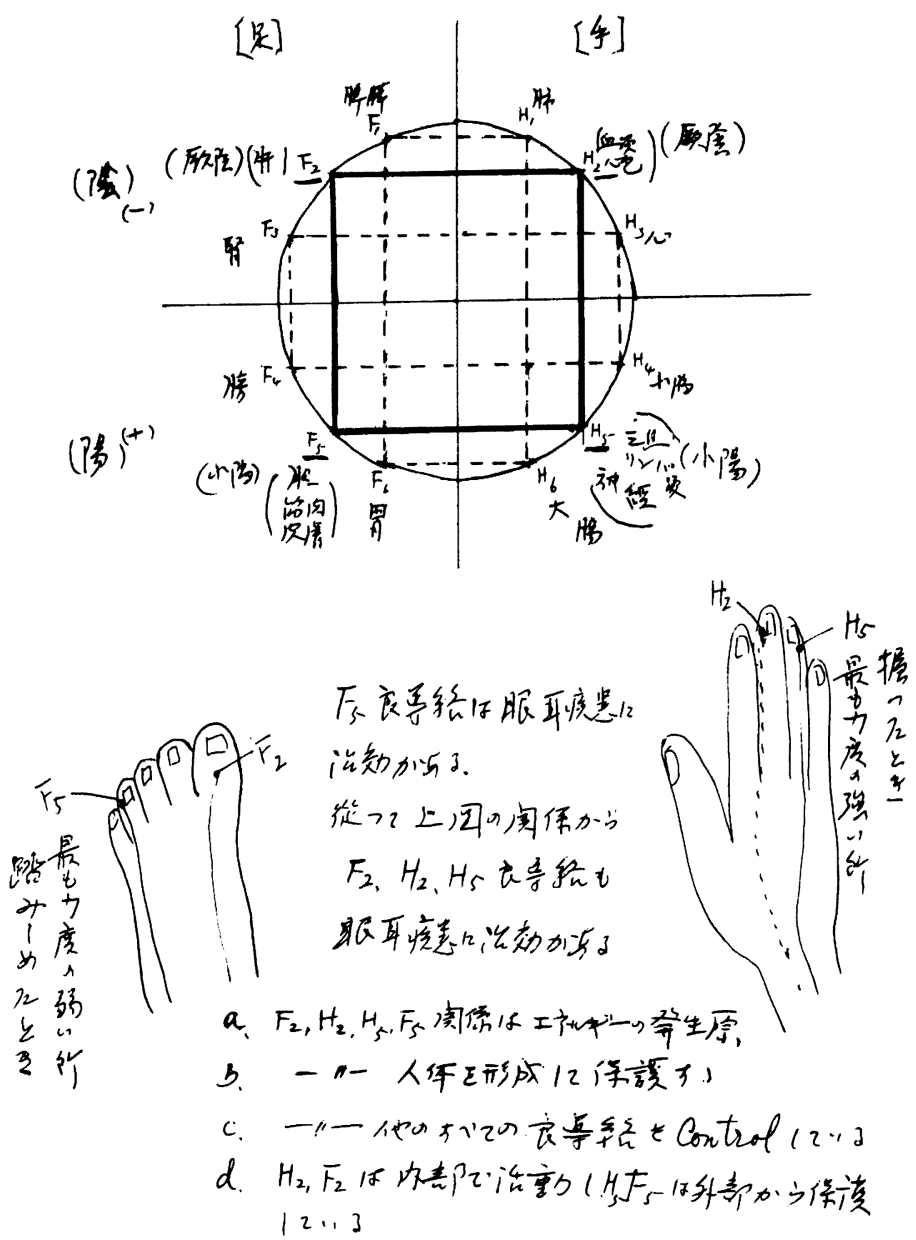
Hs良尊絡

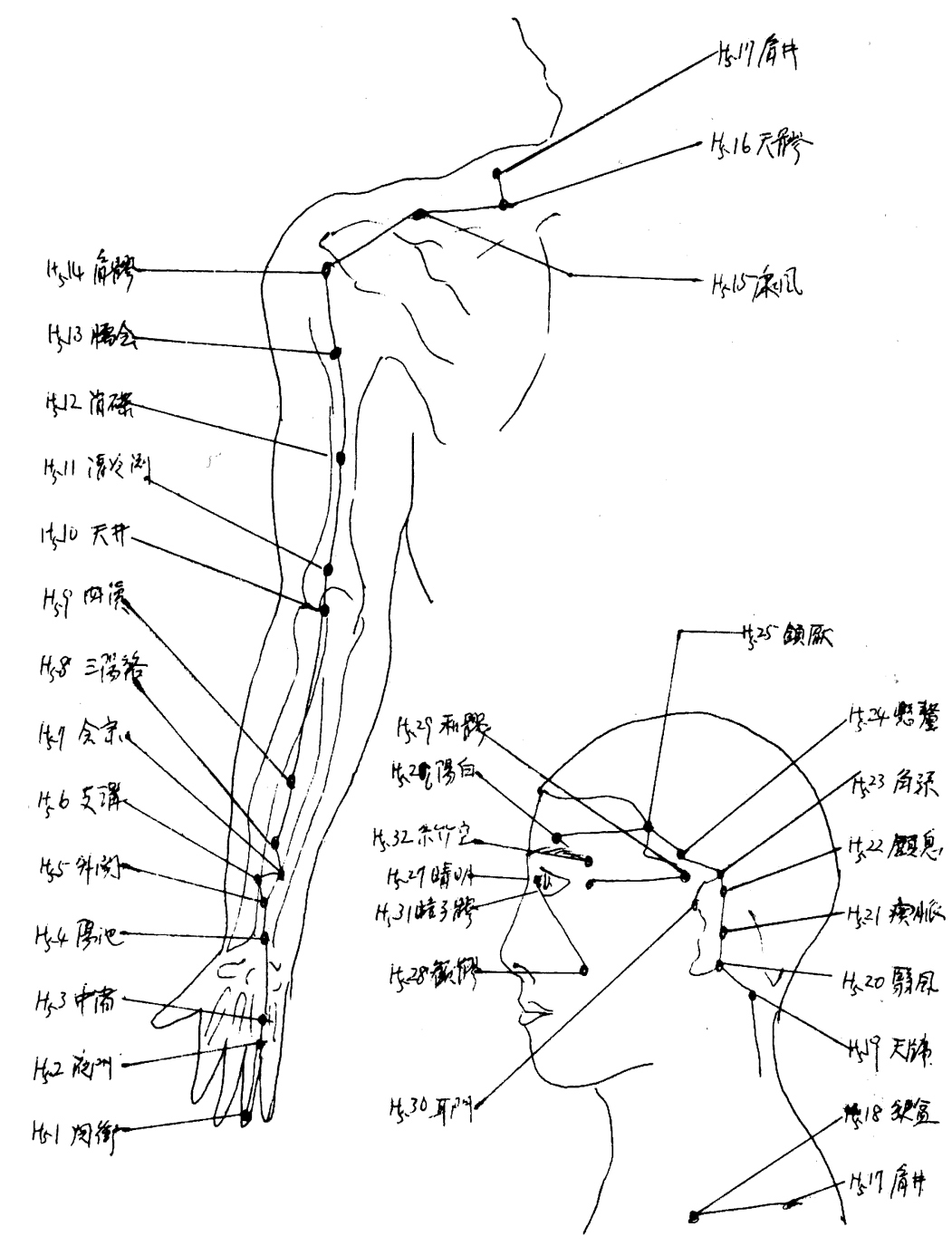




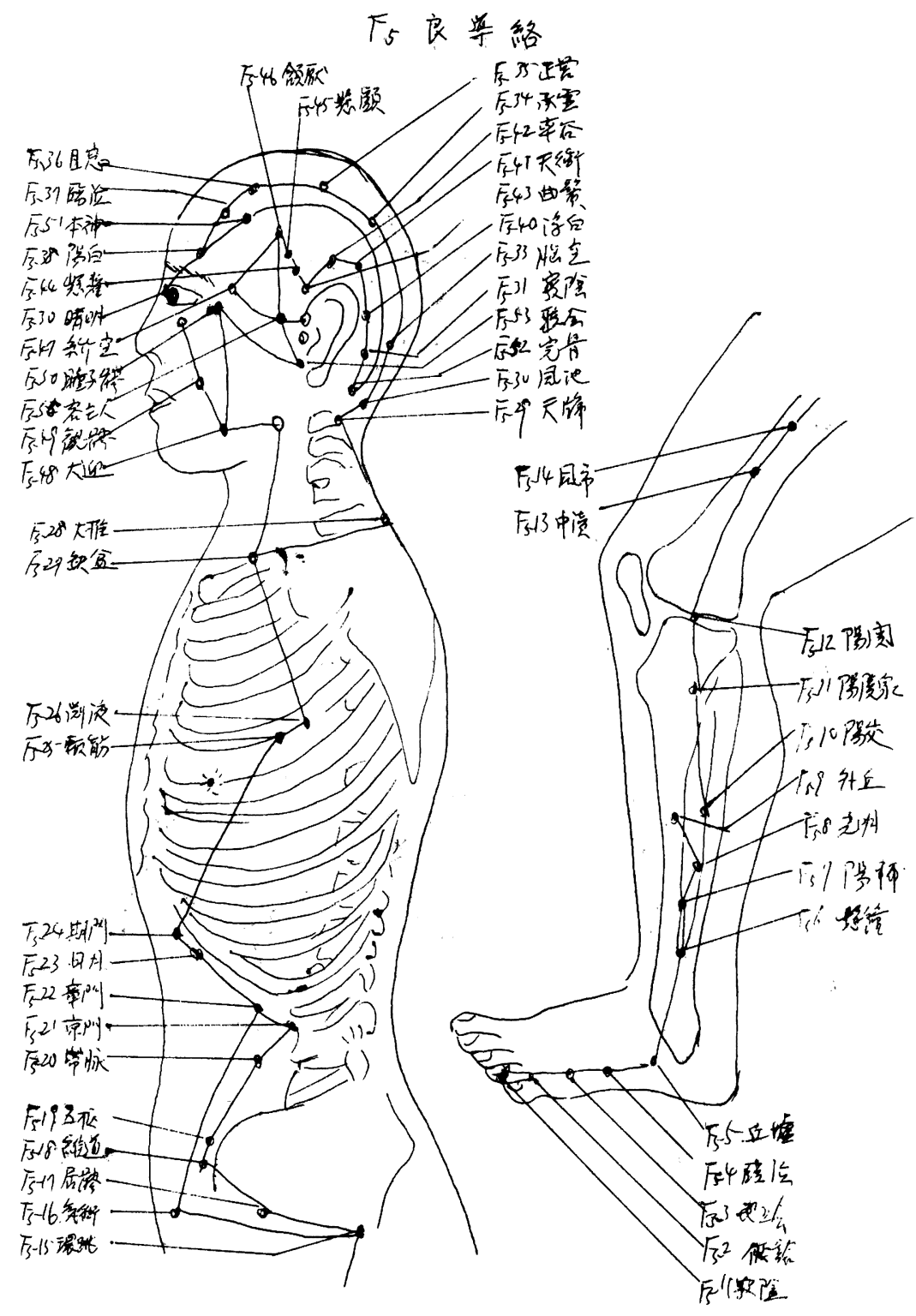

